\title{
Podstawy prawne skarbowości samorządowej w II RP
}

\section{Legal Basis of the Treasury System in Local \\ Governments in the Second Republic of Poland}

Streszczenie. Autorka przyczynku omawia pokrótce podstawę prawną systemu skarbowości komunalnej w II Rzeczypospolitej. Wskazuje na nieprzezwyciężony do wybuchu II wojny światowej problem partykularyzmów, istniejących na terenie byłych dzielnic zaborczych: pruskiej, austriackiej i rosyjskiej, czy wreszcie autonomicznego Województwa Śląskiego. Ustawa o tymczasowym uregulowaniu finansów komunalnych z 1923 r., w zamierzeniu przejściowa, doczekała się kilkudziesięciu nowelizacji, lecz nie została zastąpiona unifikacyjną regulacją. Z kolei kwestie tworzenia budżetów komunalnych, kasowości unormowane zostały w sposób ramowy w rozporządzeniu Prezydenta RP z 1924 r. o obowiązku i sposobie pokrywania wydatków przez związki komunalne oraz licznych aktach wykonawczych do tego rozporządzenia. Regulacje składały się na system, który zasadnie można oceniać jako skomplikowany, nadmiernie rozbudowany i doraźny.

Słowa kluczowe: samorząd międzywojenny; skarbowość samorządowa; podatki samorządowe; budżet samorządowy. 


\begin{abstract}
The author of the article presents the legal basis of the treasury system of the local government during the period of so called Second Republic of Poland (1918-1939) i.e. “interwar period”. The author indicates a discrepancy between systems of the former Russian, Prussian and Austrian districts, aside from the autonomous Silesian Voivodeship created in 1920, and numerous issues distinctive for process of unification, not actually successful solved until 1939. The basic provisions were provided for in Provisional settlement of communal finances Act from 1923, amended several times and officially valid until the post-war years. The matter of local budgets has been standardized in the President`s Decree from 1924 concerning obligations and procedure of covering expenditures of local governments. Nevertheless, given regulations constituted a complicated, overextended and casual system.
\end{abstract}

Keywords: treasury system of local government; II Republic of Poland; local government's revenue; local government's budget.

\title{
1. Wprowadzenie
}

Podobnie jak w przypadku innych działów prawa, prawodawca tworzący źródła komunalnego prawa skarbowego w odrodzonej Polsce skazany był na poszukiwanie modelu kompromisowego, satysfakcjonującego samorządowców z trzech byłych dzielnic, tak różnorodnych pod względem źródeł prawa komunalnego i systemów podatków miejscowych. Z dzisiejszego punktu widzenia ustawodawcę międzywojennego cechowała chaotyczność w działaniach i niejednokrotnie, zwłaszcza w pierwszej połowie lat 20., pewien „prymitywizm” legislacyjny. Wobec braku systemowego katalogu źródeł prawa pojawiały się w praktyce dyskusyjne kategorie aktów normatywnych, zaś np. rozwiązania walidacyjne czy przepisy upoważniające w świetle obecnych zasad techniki prawodawczej należałoby określić mianem niedopuszczalnych, a przynajmniej karkołomnych. Dostrzegano to. Jak wyraził się ceniony administratywista, „pierwsze nasze własne przepisy grzeszyły pod względem formy, treści

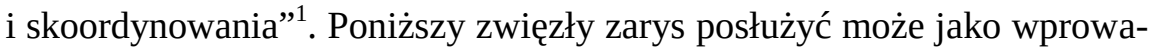

\footnotetext{
R. Hausner, Poczynania organizacyjno-oszczędnościowe w Polsce w latach 1918-1934, Warszawa 1935, s. 290.
} 
dzenie i swoisty, uproszczony przewodnik po zagadnieniu legislacji skarbowości komunalnej dla badaczy samorządowych regulacji finansowych, których interesuje stan prawny II Rzeczypospolitej.

Pierwszym wyzwaniem prawodawczym po odrodzeniu państwa było wprowadzenie regulacji tymczasowych, normujących sytuację faktyczną i konserwujących niejednokrotnie istniejące różnice prawne. Te prowizoryczne rozwiązania, choć krytykowane, wobec ogromu zadań stojących przed organami państwa często okazywały się podstawą prawną na cały okres międzywojenny ${ }^{2}$. Nie można także pominąć istniejących dysproporcji między standardami cywilizacyjnymi w poszczególnych dzielnicach zaborczych. O ile samorządy ziem zachodnich dysponowały już rozbudowaną infrastrukturą (zwłaszcza w miastach, choć nie tylko - także dawne pruskie związki prowincjonalne, przemianowane na wojewódzkie, podejmowały w ostatnich dziesięcioleciach XIX w. wiele działań na rzecz poprawy infrastruktury drogowej, kolejek wąskotorowych czy opieki zdrowotnej i socjalnej), o tyle gorsza sytuacja miała miejsce w województwach południowych i centralnych, zaś zupełnie tragiczna - na wschodzie.

\section{Legislacja w zakresie skarbowości samorządowej w latach dwudziestych}

Pierwsze działania prawodawcze w tytułowym zakresie ograniczone były do ziem byłego Królestwa Polskiego i stąd skazane były na znamię party-

2 Warto na marginesie przypomnieć, że stan badań w zakresie skarbowości międzywojennej podsumował nie tak dawno temu w sposób ogólny A. Witkowski. Por. tegoż, Dorobek badań nad skarbowościq Polski międzywojennej, [w:] „Studia z dziejów państwa i prawa polskiego", t. VIII, Lublin-Łódź 2002, s. 79-90. Kilka kolejnych przyczynków poświęconych skarbowości II RP ukazało się w pracy zbiorowej pod red. D. Bogacza i M. Tkaczuka, Podstawy materialne państwa. Zagadnienia prawnohistoryczne, Szczecin 2006, w tym opracowanie A. Tarnowskiej, poświęcone skarbowości komunalnej w województwach zachodnich Podatki jako źródło dochodów samorzq̨du b. dzielnicy pruskiej - między partykularyzmem a unifikacjq, s. 277-293. Rozdział historyczny, dotyczący dochodów samorządu terytorialnego w II RP, zawarł w swej pracy także A. Borodo. Por. tegoż, Dochody samorzq̨u terytorialnego w Polsce. Studium finansowoprawne, Toruń 1993, s. 38-67. 
kularyzmu - mowa o dekretach Naczelnika Państwa z 4 lutego 1919 r. ${ }^{3}$ i następnie 7 lutego 1919 r. ${ }^{4}$ W pozostałych dzielnicach - austriackiej i pruskiej - utrzymano w mocy obowiązujące akty prawne, dokonując w nich zmian wymuszonych przeobrażeniami ustroju samorządu. I tak zmiana przepisów galicyjskich dotyczyła prawa wyborczego do rad gminnych, prawa gmin do tworzenia związków ${ }^{5}$, a także połączenia obszarów dworskich z gminami ${ }^{6}$. Jesienią tego roku zmieniono też nieco uprawnienia podatkowe miast i powiatów, uprawniając Ministra Spraw Wewnętrznych działającego w porozumieniu z Ministrem Skarbu do wyrażania zgody na nakładanie dodatków do państwowych podatków bezpośrednich, konsumpcyjnych, podwyższania istniejących poborów przez miasta i powiaty galicyjskie ; Lwów i Kraków oraz miasta podlegające ordynacji z 1889 r. i gminy podlegające ustawie z 1896 r. mogły nakładać podatki samoistne w celu pokrycia wydatków gminnych.

Także ustawa o zasileniu finansów miejskich z 17 grudnia $1921 \mathrm{r}^{8}$ obowiązywała wyłącznie na terenie dawnego zaboru rosyjskiego i austriackiego. Przekazywała ona gminom miejskim część wpływów z państwowego podatku dochodowego, umarzała w części zadłużenie wynikłe poprzez działania podjęte w zastępstwie Skarbu Państwa, przyznawała

3 Dekret o samorządzie miejskim (Dziennik Praw Państwa Polskiego, dalej: Dz.P.P.P., $\mathrm{Nr}$ 13, poz. 140) i dekret o tymczasowej ordynacji powiatowej dla obszarów byłego zaboru rosyjskiego (Dz.P.P.P. Nr 13, poz. 141).

4 Dekret $\mathrm{w}$ przedmiocie skarbowości gmin miejskich (Dz.P.P.P. Nr 14, poz. 150) i dekret w przedmiocie skarbowości powiatowych związków komunalnych (Dz.P.P.P. Nr 14, poz. 151).

5 Ustawa z 26 lipca 1919 r., zmieniająca postanowienia galicyjskiej ustawy gminnej, obowiązująca na terytorjum b. Galicji (Dz.U. Nr 67, poz. 403).

6 Ustawa z 26 lipca 1919 r. o połączeniu obszarów dworskich z gminami, obowiązująca na terytorjum b. Galicji (Dz.U. Nr 67, poz. 404).

7 Ustawa z dnia 24 października 1919 r. w przedmiocie zmian niektórych postanowień ustaw gminnych, obowiązujących w miastach Galicji, jakoteż rozszerzenia zakresu działania galicyjskich rad miejskich (gminnych) (Dz.U.R.P. Nr 88, poz. 479) i Ustawa z dnia 24 października 1919 r. w przedmiocie częściowej zmiany §23 obowiązującej w b. Królestwie Galicji i Lodomerji z Wielkim Księstwem Krakowskiem ustawy o reprezentacji powiatowej (Dz.U. R.P. Nr 88, poz. 480).

8 Ustawa z dnia 17 grudnia 1921 r. o zasileniu finansów miejskich i o karach, nakładanych przez gminy miejskie za fałszywe zeznania podatkowe na obszarach b. zaboru rosyjskiego i austrjackiego. (Dz.U.R.P. z 1922 r. Nr 2, poz. 6). 
prawo poboru podatku obrotowego, dodatku do państwowego podatku przemysłowego, podatku od nieruchomości (tam, gdzie wcześniej pobierano podatek określony rosyjską ustawą z 1910 r.), podatku od lokali (tam, gdzie w zaborze rosyjskim pobierano do 1919 r. państwowy podatek mieszkaniowy). Ustawa zawierała także specyficzne upoważnienie dla Ministra Spraw Wewnętrznych i Ministra Skarbu, by ogłosili „z mocą obowiązującą na obszarach b. zaboru rosyjskiego i austriackiego” przedmiotowe ustawy rosyjskie. Z krytyką spotkało się jednak opóźnienie w przygotowaniu przepisów wykonawczych; co gorsza, zarzucono im zawężenie uprawnień przyznanych miastom w drodze ustawy ${ }^{9}$.

W byłym zaborze pruskim utrzymano rozwiązania niemieckie. Resort Ministra byłej Dzielnicy Pruskiej odpowiadał w latach 1919-1922 za połączenie tych ziem pod względem administracyjnoprawnym z pozostałym terytorium państwa polskiego ${ }^{10}$. Choć zadania z zakresu skarbowości stosunkowo szybko przekazano Ministrowi Skarbu i akurat unifikację w tym zakresie można uznać za satysfakcjonującą ${ }^{11}$, to proces ujednolicenia podstaw prawnych i ustroju samorządu na tych ziemiach z pozostałym terytorium kraju w zasadzie nie zakończył się do 1939 r. O specyfice tych ziem świadczył także fakt, że jedynie tu, w województwach pomorskim i poznańskim, funkcjonował realny samorząd na szczeblu ponadpowiatowym - wspomniany już dawny samorząd prowincjonalny, z sejmikiem wojewódzkim, wydziałem i starostą krajowym. Początkowo związki samorządowe $^{12}$ tej dzielnicy znajdowały się w korzystnej sytuacji - prawo pruskie, w szczególności ustawa o daninach komunalnych z 1893 r. $^{13}$

$9 \quad$ Za: A.W. Zawadzki, Finanse samorzqdu terytorialnego w latach 1918-1939, Warszawa 1971, s. 36-37.

10 Ustawa z 1 sierpnia 1919 r. o tymczasowej organizacji zarządu b. dzielnicy pruskiej (Dz.P.P.P. Nr 64, poz. 385).

11 Por. A. Gulczyński, Ministerstwo byłej Dzielnicy Pruskiej (1919-1922), Poznań 1995, w szczególności s. 87, s. 203.

12 Należy w tym miejscu uzupełnić, że takim właśnie terminem operował ustawodawca międzywojenny; dzisiejszym odpowiednikiem międzywojennego „związku samorządowego” jest jednostka samorządu terytorialnego. Podobnie określenie „komunalny” odnoszono często kompleksowo do struktur samorządowych, nie tylko miejskich.

13 Ustawa z 14 lipca 1893 o daninach komunalnych (Kommunalabgaben-Gesetz vom 14. Juli 1893; Gesetz-Sammlung für die Preussischen Königlichen Staaten, S. 152). 
przewidywało szeroki wachlarz uprawnień podatkowych. Jednak już ustawa z 17 czerwca $1921 \mathrm{r}^{14}$ rekonstruowała pobór przez samorządy zachodnie podatków przychodowych, takich jak gruntowy czy budynkowy, czym znacząco obniżyła wpływy finansowe.

Przypomnieć należy wreszcie o autonomii województwa śląskiego, nadanej w drodze ustawy konstytucyjnej z 15 lipca 1920 r. zawierającej statut organiczny województwa śląskiego ${ }^{15}$. Sejm Śląski stał się organem kompetentnym w kwestii uchwalania budżetu województwa śląskiego, zatwierdzania zamknięcia rachunków, zaciągania pożyczek wojewódzkich, obciążania majątku województwa, przyjęcia gwarancji finansowych przez skarb śląski. Szczegóły wykonywania uprawnień w zakresie skarbowości śląskiej wynikać miały z jednobrzmiących ustaw - państwowej i śląskiej. Sejm Śląski miał także teoretycznie wyrażać zgodę na wprowadzanie podatków od produkcji lub monopoli na węgiel, wyroby hutnicze. W praktyce nie doszło do realizacji wielu uprawnień sejmu, w tym podatkowych - przejęto regulacje ogólnopaństwowe. Najsilniejszym organem autonomicznego województwa stał się wojewoda - zwłaszcza w okresie urzędowania Michała Grażyńskiego (tj. 1926-1939). Wydział Skarbowy, stanowiący część składową Śląskiego Urzędu Wojewódzkiego występował w roli organu skarbowego II instancji, zaś podporządkowanemu wojewodzie Naczelnikowi Wydziału Skarbowego przypisano kompetencje Prezesa Izby Skarbowej ${ }^{16}$. W pozostałych województwach administracja skarbowa miała naturalnie niezespolony charakter.

14 Ustawa z dnia 17 czerwca 1921 r. o poborze na rzecz Skarbu Państwa dodatku do podatków: gruntowego, podymnego, domowo-klasowego i budynkowego, oraz unormowaniu poboru podatku gruntowego na obszarze województw: nowogrodzkiego, poleskiego i wołyńskiego jakoteż powiatów białostockiego, bielskiego, sokólskiego, wołkowyskiego, białowieskiego i grodzieńskiego województwa białostockiego (Dz.U. Nr 59, poz. 372). samorzqdu terytorialnego, Katowice 1939, s. 62-71; I. Weinfeld, Skarbowość polska. Zeszyt 5. Przedsiębiorstwa - Samorzq̨d - Śląsk, wyd. IV, Warszawa 1935, 425-436. 
Regulacje konstytucyjne II RP wprowadzały teoretyczne gwarancje, które nigdy nie zostały zrealizowane. Konstytucja marcowa ${ }^{17}$ zawierała przepis ustanawiający ustawowe rozgraniczenie źródeł dochodowych państwa i samorządu (art. 69) ${ }^{18}$. Próba uregulowania tej kwestii na drodze ustawy w 1926 r. skończyła się fiaskiem ${ }^{19}$. Uprzedzając nieco chronologię wywodu, wskazać można, że konstytucja kwietniowa ${ }^{20}$ nie zawierała już analogicznego przepisu; lakoniczna regulacja samorządowa akcentowała powołanie samorządu terytorialnego do realizacji zadań administracji państwowej i kwestie nadzoru rządowego ${ }^{21}$.

W sierpniu 1923 r. ujrzała wreszcie światło dzienne długo wyczekiwana ustawa o tymczasowym uregulowaniu finansów komunalnych ${ }^{22}$. Będzie to akt konstytutywny dla finansów samorządowych; choć w założeniu o przejściowym charakterze, to jednak przetrwa II Rzeczpospolitą i uchylony zostanie dopiero przez komunistyczną, powojenną władzę. Ustawodawca próbował w niej wyważyć instrumenty skarbowe funkcjonujące w trzech byłych zaborach, trudno zatem mówić o ustawie unifikacyjnej, skoro petryfikowała ona istniejące odmienne podstawy prawne, a co za tym idzie, różnice w systemach komunalnych. Wobec istniejącego niespójnego porządku prawnego, w przepisach końcowych ustawodawca pozwolił sobie na nieakceptowalną dziś ogólną klauzulę derogacyjną w brzmieniu: „przepisy ustaw, sprzeczne z niniejszą ustawą, tracą moc obowiązującą. O ile inne ustawy powołują się na takie przepisy, należy zamiast nich odpowiednio stosować przepisy niniejszej ustawy” (art. 76).

17 Konstytucja Rzeczypospolitej Polskiej z dnia 17 marca 1921 r. (Dz.U. Nr 44, poz. 267).

18 Por. W.L. Jaworski, Prawa Państwa Polskiego, Zeszyt II A. Konstytucja z dnia 17 marca 1921. Prawo polityczne od 2 października 1919 do 4 lipca 1921, Kraków 1921, s. 600-614.

19 Por. A. Zawadzki, Finanse samorzqdu terytorialnego..., s. 91-95.

20 Ustawa konstytucyjna z dnia 23 kwietnia 1935 r. (Dz.U. Nr 30, poz. 227).

21 Por. chociażby E. Gdulewicz, A. Gwiżdż, Z. Witkowski, Konstytucja Rzeczypospolitej Polskiej z 1935 r., [w:] M. Kallas (red.), Konstytucje Polski. Studia monograficzne z dziejów polskiego konstytucjonalizmu, t. 1, Warszawa 1990, s. 193.

22 Ustawa z 11 sierpnia 1923 r. o tymczasowem uregulowaniu finansów komunalnych (Dz.U. Nr 94, poz. 747). 
Rozwiązania zaproponowane w projekcie ustawy i następnie przyjęte w ustawie od razu spotkały się z ostrą krytyką ze strony opozycji parlamentarnej, samorządowców i ekonomistów. Oceniano, że ustawa nie realizuje założeń konstytucji, nie rozgranicza podatków państwowych i komunalnych (to głównie głosy pochodzące z województw centralnych; w zachodnich i południowych od dawna dominował model dodatków samorządowych do podatków państwowych), nie zezwalając na szerszą autonomię decyzyjną i uniemożliwiając samoopodatkowanie prowadzi do finansowego ubezwłasnowolnienia samorządów, likwiduje szereg drobnych podatków o istotnym znaczeniu zwłaszcza dla samorządu powiatowego $^{23}$.

Strona rządowa, broniąc regulacji jako przejściowej, nie miała świadomości, że ustawa obowiązywać będzie w praktyce aż do wybuchu II wojny światowej. Oczekiwano, że zasadniej będzie przeprowadzić najpierw unifikację ustroju samorządu. Jak wiadomo, nastąpiła ona na mocy ustawy scaleniowej dopiero w roku $1933 \mathrm{r}^{24} \mathrm{i}$ na dodatek nie miała absolutnego charakteru, pozostawiając w mocy pewne partykularyzmy byłego zaboru pruskiego.

Środki przyznane samorządom na mocy ustawy z 1923 r. okazały się niewystarczające właściwie natychmiast po wejściu ustawy w życie. Zaledwie w kilka miesięcy później rozpoczęły się prace nad jej pierwszą nowelizacją, przy czym do Sejmu wpłynęły równolegle projekty rządowy i ludowców z „Wyzwolenia”. Ten ostatni proponował pilne wprowadzenie specjalnego podatku szkolnego, jako że właśnie oświata okazała się zadaniem, na którego realizację samorządom permanentnie brakowało pieniędzy $^{25}$. Ostatecznie zamiast szerszej nowelizacji doszło tylko do „załatania dziur” w budżetach gmin wiejskich byłego zaboru rosyjskiego poprzez przyznanie im prawa do pobrania w drugim półroczu $1924 \mathrm{r}$. ograniczonego samoistnego podatku z gruntów, przemysłu, handlu i bu-

\footnotetext{
Por. A. Zawadzki, Finanse samorzq̨du terytorialnego..., s. 42-54.

Ustawa z 23 marca 1933 r. o częściowej zmianie ustroju samorządu terytorialnego (Dz.U.R.P. Nr 35, poz. 294).

25 Por. A. Zawadzki, Finanse samorządu terytorialnego..., s. 85-88.
} 
dynków na pokrycie niedoborów budżetowych ${ }^{26}$; taki rodzaj podatku wyrównawczego będzie się w przyszłości powtarzał i przetrwa ostatecznie do kresu II RP. Kwestia finansowania inwestycji szkolnych wróci w kolejnym roku, kiedy zostanie zniesiony obowiązek współudziału Skarbu Państwa w finansowaniu budowy szkół powszechnych, bez jakiegokolwiek zadośćuczynienia rosnącym w ten sposób wydatkom jednostek samorządowych.

Z kolei związki powiatowe, zobowiązane do znacznych wydatków na utrzymanie dróg, a pozbawione dotychczasowych środków finansowych, zaczęły pobierać opłaty drogowe na podstawie ustawy drogowej, co zniekształciło zakładaną przez twórców ustawy z 1923 r. strukturę dochodów jednostek powiatowych i wywołało protesty podatników. Legalność poboru tych opłat potwierdził jednak Najwyższy Trybunał Administracyjny. Jakby wbrew polityce centralnej związki samorządowe działały coraz prężniej, niejednokrotnie samodzielnie podejmując się dodatkowych zadań; przywołać w tym miejscu można rozwój sierocińców i przytułków w powiatach na szczególnie zaniedbanych ziemiach wschodnich ${ }^{27}$. Miasta z kolei wspierały się w znacznym stopniu dochodami osiąganymi przez przedsiębiorstwa komunalne, co stanowiło ukrytą formę opodatkowania mieszkańców.

Przykłady powyższe dowodzą nieprzystawalności przepisów ustawy o tymczasowym uregulowaniu finansów komunalnych do realiów. Tekst nowelizowano ogółem 44 razy $^{28}$. Ogółem doliczyć się można do 1939 r. blisko 90 rozporządzeń wykonawczych do ustawy, o najrozmaitszym zakresie i znaczeniu (przykładowo znaczna ich część dotyczyła kwestii objęcia przepisami ustawy dotyczącymi miast poszczególnych gmin wiej-

26 Na mocy ustawy z dnia 31 lipca 1924 r. o wprowadzeniu niektórych zmian w ustawie z dnia 11 sierpnia 1923 r. o tymczasowym uregulowaniu finansów komunalnych. (Dz.U. Nr 73, poz. 719).

27 Por. A. Zawadzki, Finanse samorzqdu terytorialnego..., s. 103-104, s. 176.

28 Tak wskazał w 1937 r. poseł Józef Kaczkowski - sprawozdawca kolejnej nowelizacji ustawy, podkreślając także, że w 22 przypadkach nowelizacje przyniosły zmniejszenie źródeł dochodu samorządu (Sprawozdanie Stenograficzne z 50 posiedzenia Sejmu w dn. 16 marca 1937 r., ł. 19). Autorka korzystała z cyfrowych wersji sprawozdań, dostępnych w bazie Parlamentaria II RP na stronie http://bs.sejm.gov.pl (dostęp: 30 listopada 2013 r.). 
skich). Odpowiednikiem ustawy z 1923 r. dla samorządów województwa śląskiego była ustawa z 14 kwietnia 1924 r. o tymczasowym uregulowaniu finansów komunalnych w województwie śląskim ${ }^{29}$.

Elementem działań ratunkowych składających się na reformę Grabskiego było upoważnienie Prezydenta RP do wydawania rozporządzeń na podstawie uchwał Rady Ministrów (forma aktu zresztą co najmniej dyskusyjna na gruncie rozwiązań konstytucji marcowej ${ }^{30}$ ), zawarte w ustawie z 11 stycznia 1924 r. o naprawie Skarbu Państwa i reformie walutowej ${ }^{31}$. Powołano na drodze tego umocowania szereg instytucji „oszczędnościowych” (zreformowano m.in. organ Nadzwyczajnego Komisarza Oszczędnościowego, powołano przy nim Państwową Radę Oszczędnościową, później ustanowiono komisje okręgowe) ${ }^{32}$. Ustawa przewidywała m.in. możliwość przekazania samorządom niektórych zadań wykonywanych dotąd przez administrację rządową, po zapewnieniu odpowiednich dochodów, czy też ustanowienia „obowiązku i sposobu pokrywania przez samorządu wydatków z wpływów” poprzez wprowadzenie ścisłych przepisów budżetowych i rachunkowych dla jednostek samorządowych [art.1 pkt 4) a i 4) b].

Realizując tę kompetencję prawotwórczą, Prezydent wydał 17 czerwca 1924 r. rozporządzenie o obowiązku i sposobie pokrywania wydatków przez związki komunalne ${ }^{33}$. Akt ten w sposób ramowy wskazywał zasady układania preliminarza budżetowego, dokumentowania wpływów

29 W brzmieniu ogłoszonym rozporządzeniem wojewody śląskiego z dnia 8 lipca $1926 \mathrm{r}$. w sprawie ogłoszenia ustawy z dnia 14 kwietnia 1924 r. (Dziennik Ustaw Śląskich [dalej: Dz.U.Śl.] Nr 10, poz. 47) o tymczasowem uregulowaniu finansów komunalnych w Województwie Śląskiem w brzmieniu ustawy z dnia 17 maja 1926 r. (Dz.U.Śl. Nr 14, poz. 24; Dz.U.Śl. Nr 17, poz. 30) ze zm. wprowadzonymi ustawą z 7 grudnia 1927 r. (Dz.U.Śl. Nr 26, poz. 48) i ustawą z 23 marca 1933 r. (Dz.U.Śl. Nr 9, poz. 16).

30 Doktryna współczesna i późniejsi interpretatorzy prezentowali w tej kwestii skrajnie odmienne stanowiska, por. podsumowanie dyskusji u R. Kraczkowskiego, Dekretowanie ustaw w Polsce w latach 1918-1926, Wydawnictwo Sejmowe, Warszawa 1994, s. $100-151$.

31 Ustawa z 11 stycznia 1924 r. o naprawie Skarbu Państwa i reformie walutowej (Dz.U. $\mathrm{Nr}$ 4, poz. 28). Jej kontynuatorką była ustawa z 31 lipca 1924 r. o naprawie Skarbu Państwa i poprawie gospodarstwa społecznego (Dz.U. Nr 71, poz. 687).

32 Por. szerzej R. Hausner, Poczynania organizacyjno-oszczędnościowe..., s. 94-103, s. $109-123$.

33 Dz.U. Nr 51, poz. 522. 
i wydatków jednostek samorządowych („związków komunalnych”) i kwestie nadzorcze, upoważniając zarazem Ministrów Spraw Wewnętrznych i Skarbu do „wykonania niniejszego rozporządzenia”. Lista stosownych aktów wykonawczych obejmuje w całym okresie międzywojnia 11 pozycji. Już I Rozporządzenie Ministra Spraw Wewnętrznych oraz Ministra Skarbu z 22 stycznia 1925 r. ${ }^{34}$ przekazywało uprawnienie ministrów do zatwierdzania preliminarzy budżetowych związków komunalnych wojewodom, Delegatowi Rządu w Wilnie i dyrektorom izb skarbowych. W późniejszym okresie wojewodowie działający w porozumieniu z prezesami izb skarbowych otrzymali też prawo rozstrzygania odwołań gmin od decyzji wydziałów powiatowych w sprawie zatwierdzania budżetów gminnych $^{35}$. Rozporządzenie $\mathrm{II}^{36} \mathrm{z}$ kolei precyzowało zasady zadłużania się związków komunalnych, dalece wychodząc poza ramowy §1 rozporządzenia prezydenckiego. Znacznie obszerniejsze od poprzednich rozporządzenie Ministra Spraw Wewnętrznych z 28 czerwca 1926 r. ${ }^{37}$ wprowadzało reguły tworzenia budżetu komunalnego (zawierało zasady ogólne, przepisy dotyczące budżetu administracyjnego, budżetów przedsiębiorstw komunalnych, formularza budżetowego, zaległości budżetowych, przenoszenia kredytów, budżetów dodatkowych, terminu i sposobu zestawiania preliminarza budżetowego, zatwierdzania preliminarza), zastąpione w kilka lat później zbliżonym, porządkującym rozporządzeniem z 6 grudnia 1932 r. ${ }^{38}$. Kwestii kasowości i rachunkowości dotyczyły rozporządzenia z 28 marca 1927 r. ${ }^{39}$ i następnie 6 grudnia 1932 r. ${ }^{40}$

34 Dz.U. Nr 15, poz. 99.

35 Rozporządzenie Ministra Spraw Wewnętrznych i Ministra Skarbu z 17 września 1927 r. (Dz.U. Nr 87, poz. 784).

36 Rozporządzenie II Ministra Spraw Wewnętrznych i Ministra Skarbu z 3 lutego 1926 r. (Dz.U nr 18, poz. 104).

37 Rozporządzenie Ministra Spraw Wewnętrznych z 28 czerwca 1926 r. wydane w porozumieniu z Ministrem Skarbu w sprawie wykonania $\$ 11$ punkt b) rozporządzenia Prezydenta Rzeczypospolitej z 17 czerwca 1924 r. o obowiązku i sposobie... oraz niektórych innych paragrafów tegoż rozporządzenia Prezydenta Rzeczypospolitej.

38 Rozporządzenie Ministra Spraw Wewnętrznych z 6 grudnia 1932 r. wydane w porozumieniu z ministrem Skarbu o sporządzaniu i ustalaniu budżetów związków komunalnych (Dz.U. Nr 71, poz. 168).

39 Rozporządzenie Ministra Spraw Wewnętrznych i Ministra Skarbu z 28 marca 1927 r. o kasowości i rachunkowości związków komunalnych (Dz.U. Nr 38, poz. 345). 
Akcja oszczędnościowa w odniesieniu do samorządów przejawiała się m.in. w powołaniu Komisji Wojewódzkich, a następnie po ich likwidacji utworzenia przy wspomnianych komisjach okręgowych Sekcji Samorządowych, a także ustanowieniu szczególnego nadzoru w postaci delegatów rządowych przy związkach samorządowych ${ }^{41}$.

W 1928 r. przyjęto regulacje dotyczące związków międzykomunalnych $^{42}$. Dla spraw skarbowości istotne znaczenie miały przepisy dotyczące odrębności majątku międzykomunalnego, zasad administrowania nim, zasad nadzoru, odpowiedzialności majątkowej za przyjęte zobowiązania.

\section{Akcja oszczędnościowo-oddłużeniowa w latach trzydziestych}

Przejściowa stabilizacja waluty przyniosła samorządom nowe perspektywy inwestycyjne, czemu sprzyjały w pierwszej fazie koniunktury tzw. „pożyczki ulenowskie” - kredyt inwestycyjny dla 10 miast średniej wielkości, zaciągnięty za pośrednictwem Skarbu Państwa i Banku Gospodarstwa Krajowego (BGK) w znanym nowojorskim koncernie budowlanym Ulen \& Company (Amerykanie realizowali kredyt, wykonując inwestycje m.in. w Piotrkowie i Lublinie). Innym źródłem finansowania inwestycji samorządowych były pożyczki ulgowe Ministerstwa Robót Publicznych ${ }^{43}$. Prawdziwy boom budowlany, zwłaszcza w Polsce centralnej, rozpoczął się w 1927 r. W tym też roku utworzono Komunalny Fundusz Pożyczko-

40 Rozporządzenie Ministra Spraw Wewnętrznych z 6 grudnia 1932 r. wydane w porozumieniu z Ministrem Skarbu o kasowości i rachunkowości związków komunalnych (Dz.U. z 1933 r. Nr 11, poz. 72).

41 Por. R. Hausner, Poczynania organizacyjno-oszczędnościowe..., s. 123-130.

42 Rozporządzenie Prezydenta Rzeczypospolitej z 22 marca 1928 r. o związkach międzykomunalnych (Dz.U. Nr 39, poz. 386), przepisy wykonawcze znalazły się w rozporządzeniu Ministra Spraw Wewnętrznych z dnia 22 lipca 1929 r. wydane w porozumieniu z Ministrami: Skarbu, Sprawiedliwości, Wyznań Religijnych i Oświecenia Publicznego, Rolnictwa, Przemysłu i Handlu, Komunikacji, Robót Publicznych oraz Pracy i Opieki Społecznej w sprawie wykonania rozporządzenia Prezydenta Rzeczypospolitej z dnia 22 marca 1928 roku o związkach międzykomunalnych (Dz.U. Nr 60, poz. 469).

43 Por. Oddłużenie samorzq̨du terytorialnego. Sprawozdanie Centralnej Komisji Oszczędnościowo-Oddłużeniowej dla Samorzq̨du, Warszawa 1937, s. 12-13, s. 59-60. 
wo-Zapomogowy ${ }^{44}$. Samorządy masowo korzystały z kredytów długoterminowych udzielanych przez banki państwowe, z BGK na czele, ale wspomnieć można też instytucje komunalne - Polski Bank Komunalny, Komunalny Bank Kredytowy z Poznania, Wojewódzki Bank Pożyczkowy z Poznania czy Pomorską Krajową Kasę Pożyczkową z Torunia. Wielki kryzys przełomu lat 20. i 30. spowodował zamknięcie wielu źródeł finansowania inwestycji. W celu ich dokończenia związki komunalne zwróciły się ku droższym instrumentom finansowym, także zagranicznym (m.in. Warszawa i Gdynia zaciągały pożyczki w Szwajcarii, Poznań w Wielkiej Brytanii, Włocławek - w Szwecji ${ }^{45}$. Zadłużenie jednostek samorządowych sięgnęło $880 \mathrm{mln}$ zł, z czego do $300 \mathrm{mln}$ przypadało na zobowiązania krótkoterminowe. Samorządy zaczęły przetrzymywać kwoty zebrane na poczet podatków państwowych, zaniedbywały wypłaty wynagrodzeń, realizację zadań z zakresu opieki społecznej czy oświaty.

Kryzys obciążył budżety samorządowe znacznie bardziej niż budżet państwa. Jednak rząd nie od razu podjął zdecydowane działania sanacyjne, przeciwnie wręcz - w celu równoważenia budżetu państwa przejmowano na rzecz Skarbu Państwa niektóre z dotychczasowych dochodów samorządowych $^{46}$. Skądinąd nie dziwi takie stanowisko; w optyce obozu rządzącego, odchodzącego od pozostałości naturalistycznej doktryny pouvoir municipal na rzecz rygorystycznej doktryny państwowej, administracja samorządowa zajmować się miała wyłącznie realizacją zadań administracji państwowej pod ścisłym nadzorem organów rządowych. Założenie to odzwierciedlą przepisy ustawy scaleniowej z 1933 r. i niebawem konstytucji kwietniowej.

Wstępną reakcją na masową zapaść finansową samorządów było powołanie przez Prezesa Rady Ministrów Komisji Uzdrowienia Gospodarki

44 Na mocy rozporządzenia Prezydenta RP z 1 czerwca 1927 r. o utworzeniu komunalnego funduszu pożyczkowo-zapomogowego oraz częściowej zmianie ustawy z dnia 11 sierpnia 1923 r. o tymczasowem uregulowaniu finansów komunalnych i częściowej zmianie rozporządzenia Prezydenta Rzeczypospolitej z dnia 17 czerwca 1924 r. o obowiązku i sposobie pokrywania wydatków przez związki komunalne (Dz.U. Nr 50, poz. 448).

45 Por. Oddłużenie..., s. 14-16; A. Zawadzki, Finanse samorzqdu terytorialnego..., s. $130-136$.

46 Por. A. Zawadzki, Finanse samorzq̨u terytorialnego..., s. 145, s. 189-196. 
Komunalnej, a na skutek jej działalności - wydanie przez Prezydenta rozporządzeń z 21 października 1932 r. w sprawie obniżenia kosztów administracji komunalnej ${ }^{47}$ oraz z 27 października 1932 r. o dochodzeniu roszczeń pieniężnych i egzekucji należności pieniężnych, opartych na tytułach prywatnoprawnych, przypadających od związków samorządowych $^{48}$. Pierwsze z nich powoływało m.in. kolejny raz wojewódzkie komisje oszczędnościowe; krok ten samorządowcy przyjęli krytycznie, upatrując w ich działalności ponoszenia niepotrzebnych w dobie kryzysu kosztów. Wnioski z analiz komisji były dosyć oczywiste - stwierdzono stałe zwiększanie się ilości i zakresu zadań zleconych przez administrację rządową i zbyt silny nacisk ze strony wierzycieli ${ }^{49}$. Drugie ze wspomnianych rozporządzeń wprowadzało m.in. instytucję dochodzenia roszczeń za pośrednictwem władz nadzorczych. Celem rozwiązań było wyeliminowanie niebezpieczeństwa zaprzestania wykonywania zadań publicznych przez związek, wobec którego prowadzona byłaby „zbyt skuteczna” egzekucja zobowiązań prywatnoprawnych. W 1933 r. za pośrednictwem komisji powołanych przy izbach skarbowych przeprowadzono akcję rozliczania wzajemnych należności związków komunalnych i Skarbu Państwa.

Wypracowaniu długofalowej perspektywy naprawy finansów samorządowych służyć miało powołanie przy Prezesie Rady Ministrów kolejnej już z długiej listy ciał eksperckich, Komisji ds. Samorządu Terytorialnego ${ }^{50}$. Tezy wypracowane przez komisję legły u podstaw kolejnych rozporządzeń prezydenckich, wydanych 24 października 1934 r.: o poprawie gospodarki i finansów związków samorządowych ${ }^{51}$ oraz o Związku Rewizyjnym Samorządu Terytorialnego ${ }^{52}$. Pierwsze z nich przewidywało szereg środków zmniejszających wydatki na obsługę długów oraz wydatków administracyjnych, m.in. poprzez ograniczenie lub zawieszenie pewnych zadań związku. Utrzymano ponadto koncepcję komisji wojewódzkich, nadając im charakter oszczędnościowo-oddłużeniowych, i powołano Cen-

\footnotetext{
Dz.U. Nr 91, poz. 777.

Dz.U. Nr 94, poz. 809.

Por. Oddłużenie..., s. 22.

Tamże, s. 24.

Dz.U. Nr 94, poz. 846 ze zm.

Dz.U. Nr 94, poz. 847.
} 
tralną Komisję Oszczędnościowo-Oddłużeniową (dalej: CKOO) przy Prezesie Rady Ministrów (od 1936 r. przy Ministrze Skarbu). Skład komisji miał mieszany charakter, poza przedstawicielami administracji rządowej znaleźć się w nich mieli przedstawiciele głównych wierzycieli (w art. 10 ust. 1 rozporządzenia wskazani jako „członkowie powołani przez Ministra Spraw Wewnętrznych w porozumieniu z Ministrem Skarbu i Ministrem Przemysłu i Handlu na wniosek przewodniczącego komisji”) oraz czynnik społeczny (reprezentanci samorządowych lub quasisamorządowych organów wojewódzkich, w zależności od terytorium) ${ }^{53}$. Pożądane poszerzenie uprawnień CKOO i uproszczenie procedur oddłużeniowych nastąpiło na mocy dekretu Prezydenta z 14 listopada 1935 r. ${ }^{54}$, wówczas akcja oddłużeniowa nabrała tempa. Z inicjatywy CKOO doszło do wydania dekretu Prezydenta o ulgach w spłacie niektórych zobowiązań gmin wiejskich ${ }^{55}$.

Przyjęte regulacje budziły rozliczne wątpliwości natury prawnej, m.in. podważano przyznanie CKOO kompetencji do umarzania zobowiązań związków wobec wierzycieli publicznoprawnych ${ }^{56}$. Odpowiedzią na niemal 300 skarg do Najwyższego Trybunału Administracyjnego było formalne zakończenie akcji oddłużeniowej i przekazanie spraw spornych

53 Organizację i tryb działania komisji uregulowały rozporządzenie Prezesa Rady Ministrów z dnia 26 marca 1935 r. wydane w porozumieniu z Ministrami: Spraw Wewnętrznych, Skarbu oraz Przemysłu i Handlu w sprawie organizacji i trybu postępowania Centralnej Komisji Oszczędnościowo-Oddłużeniowej dla Samorządu (Dz.U. Nr 22, poz. 132) oraz rozporządzenie Ministrów: Spraw Wewnętrznych, Skarbu, oraz Przemysłu i Handlu z dnia 16 kwietnia 1935 r. o organizacji i trybie postępowania komisyj oszczędnościowo-oddłużeniowych dla samorządu (Dz.U Nr 31, poz. 231), a następnie rozporządzenie Ministra Skarbu i Ministra Spraw Wewnętrznych z dnia 31 lipca 1936 r. wydane w porozumieniu z Ministrem Przemysłu i Handlu o zmianie rozporządzenia Prezesa Rady Ministrów z dnia 26 marca 1935 r. w sprawie organizacji i trybu postępowania Centralnej Komisji Oszczędnościowo-Oddłużeniowej dla Samorządu (Dz.U. 63, poz. 460).

54 Dekret Prezydenta Rzeczypospolitej z dnia 14 listopada 1935 r. w sprawie zmiany rozporządzenia Prezydenta Rzeczypospolitej z dnia 24 października 1934 r. o poprawie gospodarki i finansów związków samorządowych. (Dz.U. Nr 82, poz. 506).

55 Dekret Prezydenta Rzeczypospolitej z dnia 3 listopada 1936 r. o ulgach w spłacie niektórych zobowiązań gmin wiejskich (Dz.U. Nr 84, poz. 584).

56 Por. Oddłużenie..., s. 44-45. 
Urzędowi Rozjemczemu na mocy ustawy z 29 marca 1937 r. ${ }^{57}$ Ustawa wskazywała m.in. terminy wygasania kompetencji CKOO i komisji wojewódzkich w orzekaniu ulg oddłużeniowych. Akcja, choć przyniosła widoczną poprawę, nie zagwarantowała procesu dalszego obniżania kosztów obsługi długów samorządowych ani nie zrewidowała gospodarek samorządowych.

Debaty sejmowe ostatnich przedwojennych lat nie przyniosły istotnych rozstrzygnięć normatywnych. Wprawdzie na posiedzeniu Sejmu w grudniu 1937 r. Minister Skarbu Eugeniusz Kwiatkowski optymistycznie uznał, że pełna reforma finansów samorządowych zajmie trzy lata, zaproponował 10-milionową doroczną dotację na funkcjonowanie samorządów wypłacaną w miesięcznych transzach i jako pozytywny krok wskazał odciążenie samorządów gminnych przez przejęcie przez Skarb Państwa wypłaty dodatków mieszkaniowych dla nauczycieli ${ }^{58}$, to jednak realnie podejmowane działania nadal miały przejściowy charakter ${ }^{59}$.

Kres międzywojennego systemu skarbowości samorządowej przyniosły trzy akty prawne. Wskazać należy w tym miejscu dekret o reformie samorządowego systemu podatkowego z 13 kwietnia 1945 r. $^{60}$, zawieszający na okres do końca 1945 r. szereg międzywojennych przepisów, w tym ustawy o tymczasowym uregulowaniu finansów komunalnych, dekret z 20 marca 1946 r. o finansach komunalnych ${ }^{61}$, uchylający już niemal w całości ustawę z 1923 r. i finalnie zatwierdzony przez Radę Państwa dekret Rady Ministrów z 11 czerwca 1947 r. prawo karne skarbowe $^{62}$, uchylający ostatnie z obowiązujących przepisów ustawy z 1923 r.

57 Ustawa z dnia 29 marca 1937 r. o zakończeniu akcji oddłużenia związków samorządowych (Dz.U. Nr 24, poz. 151).

58$$
-52 \text {. }
$$

59 Ostatnia jak się zdaje nowelizacja ustawy z 1923 r., ustawa z 5 sierpnia 1938 r. o poprawie finansów związków samorządu terytorialnego i o zmianie ustawy o tymczasowym uregulowaniu finansów komunalnych (Dz.U. Nr 59, poz. 455).

Dz.U. Nr 13, poz. 73.

Dz.U. Nr 19, poz. 129.

Dz.U. Nr 32, poz. 140. 


\section{Podsumowanie}

Jak wynika z powyższych uwag, cechą charakteryzującą wiele rozwiązań dla finansów samorządów w okresie międzywojennym była ich zakładana a prori tymczasowość, podczas gdy w istocie prowizoryczny stan prawny trwał lata, niejednokrotnie do 1939 r. (jak „tymczasowa” już z tytułu ustawa z 1923 r. czy tymczasowy podatek wyrównawczy dla gmin byłego zaboru rosyjskiego). Zwraca uwagę skala olbrzymich trudności związanych z procesem zastępowania prawa dzielnicowego zunifikowanymi regulacjami. Do 1939 r. pozostawały w mocy np. niektóre pruskie przepisy komunalne.

Abstrahując jednak od szeregu trudności formalnych, także za pomocą przepisów merytorycznych nie udało się stworzyć w pierwszym dziesięcioleciu II RP precyzyjnego systemu finansowania samorządów, które niebawem, po okresie przeinwestowania, który zbiegł się ze światowym kryzysem gospodarczym, dosięgła zapaść budżetowa. Naturalnie jedną z zasadniczych przyczyn zadłużenia pozostawał brak równowagi między dochodami a wydatkami, wiążącymi się z wykonywaniem rosnącej puli zadań z zakresu administracji publicznej. Państwo przedłożyło interes Skarbu Państwa nad uzdrowienie finansowania wspólnot lokalnych. Konstytucyjna gwarancja rozdzielenia źródeł finansowych i przepisy ustawy z 1923 r. zastrzegające, że nałożenie nowych obowiązków uwarunkowane jest zapewnieniem związkom samorządowym źródeł finansowania, pozostały wyłącznie na papierze. Następował wręcz odwrotny proces - pomniejszania poprzez nowelizacje ustawy z 1923 r. przychodów samorządowych. Ustawodawstwo lat trzydziestych służyło już głównie przeprowadzeniu akcji oszczędnościowo-oddłużeniowej, której efekty można uznać za zadowalające. Budżety jednostek samorządowych w przeważającej mierze uległy zrównoważeniu. Końcówka lat 30. nie przyniosła jednak gorąco wyczekiwanego przez działaczy samorządowych finału w postaci gruntownego uporządkowania systemu skarbowości samorządowej.

W 1950 r. względy polityczne doprowadziły ostatecznie do likwidacji samorządu terytorialnego na cztery dekady. Choć po reaktywacji sa- 
morządu terytorialnego w 1990 r. przyjęto szereg systemowych rozwiązań instytucjonalnych, problem niedoborów finansowych także współczesnym samorządowcom nie pozostaje obcy.

\section{Bibliografia:}

Bogacz D., Tkaczuk M. (red.), Podstawy materialne państwa, Wydawnictwo Naukowe Uniwersytetu Szczecińskiego, Szczecin 2006.

Borodo A., Dochody samorzq̨du terytorialnego. w Polsce. Studium finansowoprawne, Wydawnictwo Uniwersytetu Mikołaja Kopernika, Toruń 1993.

Gdulewicz E., Gwiżdż A., Witkowski Z., Konstytucja Rzeczypospolitej Polskiej z 1935 r. [w:] M. Kallas (red.), Konstytucje Polski. Studia monograficzne z dziejów polskiego konstytucjonalizmu, t. 1, Państwowe Wydawnictwo Naukowe, Warszawa 1990, s. 141-216.

Gulczyński A., Ministerstwo byłej Dzielnicy Pruskiej (1919-1922), Wydawnictwo Poznańskiego Towarzystwa Przyjaciół Nauk, Poznań 1995.

Hausner R., Poczynania organizacyjno-oszczędnościowe w Polsce w latach 1918-1934, Drukarnia Gaz. Adm. i P.P., Warszawa 1935.

Jaworski W.L., Prawa Państwa Polskiego, Zeszyt II A. Konstytucja z dnia 17 marca 1921. Prawo polityczne od 2 października 1919 do 4 lipca 1921, Krakowska Spółka Wydawnicza, Kraków 1921.

Kallas M. (red.), Konstytucje Polski. Studia monograficzne z dziejów polskiego konstytucjonalizmu, Państwowe Wydawnictwo Naukowe, Warszawa 1990.

Kraczkowski R., Dekretowanie ustaw w Polsce w latach 1918-1926, Wydawnictwo Sejmowe, Warszawa 1994.

Kokot K., Zakres działania województwa ślq̨skiego jako jednostki samorzqdu terytorialnego, Wydawnictwa Instytutu Śląskiego, Katowice 1939.

Oddłużenie samorzq̨du terytorialnego. Sprawozdanie Centralnej Komisji Oszczędnościowo-Oddłużeniowej dla Samorzq̨du, Warszawa 1937.

Tarnowska A., Podatki jako źródło dochodów samorzq̨u b. dzielnicy pruskiejmiędzy partykularyzmem a unifikacjq, [w:] D. Bogacz, M. Tkaczuk (red.), Podstawy materialne państwa. Zagadnienia historyczno-prawne, Wydawnictwo Naukowe Uniwersytetu Szczecińskiego, Szczecin 2006, s. 277-293.

Weinfeld I., Skarbowość polska. Zeszyt 5. Przedsiębiorstwa - Samorzq̨d - Ślq̨sk, wyd. IV, Wydawnictwo „Bibljoteka Prawnicza”, Warszawa 1935. 
Witkowski A., Dorobek badań nad skarbowościq Polski międzywojennej, [w:] „Studia z dziejów państwa i prawa polskiego”, t. VIII, Lublin-Łódź 2002, s. 79-90.

Zawadzki A. W., Finanse samorzqdu terytorialnego w latach 1918-1939, Państwowe Wydawnictwo Ekonomiczne, Warszawa 1971. 